\title{
Impact of COVID-19 Pandemic on Pharmacy Teaching at a Midwestern University
}

\author{
Lisa M. Richter \\ North Dakota State University \\ David M. Scott \\ North Dakota State University \\ Amer Bektas \\ North Dakota State University \\ Daniel L. Friesner \\ North Dakota State University \\ Charles D. Peterson \\ North Dakota State University
}

The coronavirus (COVID-19) pandemic severely impacted higher education institutions. In March 2020, the North Dakota State University School of Pharmacy notified faculty and students that the remainder of the semester would be taught using remote learning. The study objective is to determine how the change from the traditional classroom to remote learning impacted students and faculty. Pharmacy students were surveyed to ascertain how the transition to remote learning have impacted their learning. Additionally, faculty were surveyed using a semi-structured interview to assess their instructional efforts. The student survey findings identify several challenges impacting instruction, including online exam-taking and balancing time constraints. Faculty survey responses collected include themes of decreased student engagement, technology use and access, and transitions in the learning environment. Curriculum areas facing significant challenges during the pandemic include hands-on laboratory skills and experiential education which required multiple changes. Despite the challenges, faculty made the teaching transitions that they might not have otherwise tried. Assessing the impact of remote learning will continue to be important as the pandemic continues.

Keywords: assessment, epidemic, pharmacy education, web-based learning

\section{INTRODUCTION}

Coronavirus disease 2019 (COVID-19) is an infectious disease caused by the severe acute respiratory syndrome coronavirus 2. The disease was first identified in December 2019 in Wuhan, the capital of 
China's Hubei province, and has since spread globally, resulting in the ongoing 2019-20 coronavirus pandemic (Hui et al., 2020). On January 19, 2020, the first patient case with COVID-19 was reported in Washington State and one day later became the first reported death in the United States (Kim et al., 2020).

The virus is primarily spread during close contact by small droplets when people cough, sneeze, or talk. Preventive measures to reduce the chances of infection include staying at home, avoiding crowded places, appropriate hand washing, masking, and practicing good respiratory hygiene. Another preventive measure is the use of social distancing strategies (staying at least six feet apart from others) whose aim is to reduce contact of infected persons with large groups by closing schools and workplaces, restricting travel, and cancelling mass gatherings (World Health Organization, 2020). While recommended by public health experts, there has been a wide variance in how states, and organizations within states (including colleges and universities), operationalized and enforced social distancing requirements. Most public and private schools in all 50 states and the District of Columbia took extreme measures to limit the spread of COVID19 (Education Week, 2020). For example, many higher education institutions canceled classes and moved other classes to remote instruction in response to the outbreak (Hadden et al., 2020).

The use of telemedicine (telehealth) in public health emergencies is widely documented and it is being used to meet the COVID-19 crisis (Hollander \& Carr, 2020; Lurie \& Carr, 2018). Because health professions programs are subject to decision-making by the college/university, many health professions programs were required to cease traditional classroom instruction and move to remote (virtual) learning. However, technology-mediated instruction disproportionately (and negatively) impacts health professions programs (including pharmacy programs) with respect to the vocational and experiential aspects of pharmacy education. It requires new skills and institutional infrastructure, and it is time and labor intensive, requiring more than simply recording a lecture and posting slides (Woolliscroft, 2020). As an example, it is relatively straightforward to use telehealth technologies to teach students how to educate patients on the management of a chronic condition. It is more challenging to use the technology to teach students how to appropriately administer an immunization or take a patient's blood pressure.

As noted above, many universities have implemented a variety of measures to reduce student exposure to the coronavirus by offering coursework remotely. Kebritchi and Lipschuetz conducted a meta-analysis that reviewed teaching and learning issues associated with online learning. Overall, they reviewed 104 articles on online courses of which included 25 on learners' issues, 23 focused on content design, 45 focused on issues related to instructors' issues, and 11 focused on mixed issues of instructors, learners, and content (Kebritchi et al., 2017). Moule and Ward study looked at the use of E-learning in higher education programs and 24 of 25 institutions used virtual learning (e.g., Blackboard, email, discussion boards). Some nursing students mentioned the difficulty of access to online platforms and frustration with the lack of group commitment to collaborative online learning. The concerns they have are likely comparable to our situation (and those of other pharmacy programs worldwide) so it helped guide our survey development (Anderson et al., 2009; Brazeau \& Romanelli, 2020; Fuller et al., 2020; Lyons et al., 2020; Moule et al., 2010; Murphy, 2020; Schlesselman et al., 2020; Volery \& Lord, 2000).

Lyons et al. (2020) described the COVID-19 pandemic impact on pharmacy educators in the Australia and Malaysia region in delivering remote teaching. They reduced content and used asynchronous learning to be attentive to student needs. The authors recommended the need for schools of pharmacy worldwide to work together and endorse global curricula as other health professions are considering. Fuller et al. (2020) reported on the impact that COVID-19 has made in pharmacy experiential education at the University of North Carolina (UNC). At UNC, faculty members are engaging students in virtual rounds, telemedicine services, medication counseling via phone, and remote electronic medication record documentation. Schlesselman et al. (2020) report that during times of stress, pharmacy students handle the experience in different ways. They recommend that colleges/schools should consider strategies to assist students with the stress induced by the COVID-19 pandemic. Programs should use strategies to build students' resilience and improve their well-being, realizing that any one approach will not meet the needs of all students. 


\section{Study Objective}

On March 21, 2020, North Dakota State University (NDSU) made the decision to move from traditional, in-class instruction to remote instruction for the remainder of the semester. At that time, the NDSU College of Health Professions, School of Pharmacy (SoP) faculty, staff, and students were notified by the University's administration of its decision to convert to remote learning methods. Because the impact of these remote learning changes is unknown, a virtual (ongoing, longitudinal) survey was developed and administered to obtain feedback from students. This represents Part 1 of our study. Part 2 of the study consists of a one-time survey (interview) that was developed and administered to SoP faculty. The study objective was to use information from these interventions to characterize how the change from the traditional classroom to remote learning affected faculty and students.

\section{METHODS}

\section{Communication Technology and On-Line Pharmacy Education}

Given the need for social distancing due to the COVID-19, many pharmacy schools have implemented a variety of remote teaching measures. NDSU has experience with real-time audio-visual communication technologies, both in pharmacy practice settings and in teaching remote (distance-based) coursework. Since 2002, NDSU has worked with community pharmacists and rural hospital pharmacists throughout North Dakota to develop a sustainable telepharmacy model (Brown et al., 2017; Peterson et al., 2010; Scott et al., 2017). Since 2013, the Masters in Public Health (MPH) program at NDSU has offered courses by two pathways - by distance (satellite communications through the North Dakota Interactive Video Network (IVN)) and by the traditional classroom (Friesner et al., 2010; Naughton et al., 2010). The University's decision to move to fully remote learning required faculty, staff, and students to use these communication technologies for new purposes, and in new ways. Critical in this transition to remote learning is how the SoP managed (and assessed the outcomes of) this transition to ensure that the needs of its key stakeholders (including Doctor of Pharmacy students) were met.

\section{Student Survey Design and Administration}

The SoP's administrative leadership team developed an on-going virtual survey as a tool to allow our students to voice concerns directly to the administrative leadership team. Students could complete the survey as often as they liked (e.g., hourly, daily, weekly) to allow for continuous feedback. The survey also served as a means for the SOP's administrative leadership team to stay connected with its students, which were dispersed across the state and region. The fourth author was assigned to collate, summarize, and report the weekly student survey findings to the SoP's administrative leadership team (and others) to help develop a weekly action plan for the Doctor of Pharmacy program and its students.

Virtual Zoom meetings were used to discuss these student issues and needs with both the College of Health Professions and School of Pharmacy administrative leadership teams. An implementation plan was subsequently developed and communicated to students, so they were aware that action was being taken to address their concerns.

\section{Faculty Survey Design and Administration}

Interviews were held in July 2020 with faculty members in a School of Pharmacy (SoP) who were employed by the University during the start of the COVID-19 pandemic. Faculty members, including individuals from the Department of Pharmacy Practice, the Department of Pharmaceutical Sciences, and other SoP administrators were asked to participate. A questionnaire was developed by two members (the third and fourth authors) of the research team. The questionnaire included eight multiple choice demographic questions (Table 1) followed by 13 short answer questions (Appendix 1). All questions were asked to each respondent using a semi-structured interview (qualitative) format (Forister \& Blessing, 2020, p. 118). One investigator (the third author) conducted all individual interviews with participants via phone, video communication or in-person. Verbal consent was recorded by the individual (the third author) administering the survey. This author read the questions and transcribed a summary of the individual's 
response. The research protocol and procedures were reviewed and approved by the Institutional Review Board at North Dakota State University.

TABLE 1

DEMOGRAPHICS OF FACULTY WHO PARTICIPATED IN A COVID-19 DISTANCE LEARNING SURVEY $(\mathbf{N}=\mathbf{2 2})$

\begin{tabular}{ll}
\hline Variable & No. (\%) \\
\hline Age & \\
Less than 30 years old & $0(0)$ \\
$30-39$ years old & $9(41)$ \\
$40-49$ years old & $6(27)$ \\
$50-59$ years old & $4(18)$ \\
Greater than 59 years old & $3(14)$ \\
Type of course(s) taught & $5(23)$ \\
Didactic & $0(0)$ \\
Experiential & $17(77)$ \\
Both didactic \& experiential & \\
Department & $18(82)$ \\
Pharmacy Practice & $4(18)$ \\
Pharmaceutical Science & $20(91)$ \\
Taught spring 2020 & $2(9)$ \\
Yes & $7(32)$ \\
No (involved in COVID transition in other ways) & $6(27)$ \\
Years teaching at North Dakota State University & $2(9)$ \\
0-5 years & $7(32)$ \\
6-10 years & \\
11-15 years & $7(32)$ \\
Greater than 15 years & $15(68)$ \\
Previous experience with distance or online education & $19(86)$ \\
Yes & $0(0)$ \\
No & $3(14)$ \\
Preferred course delivery method prior to spring 2020 & $9(41)$ \\
Synchronous & $4(18)$ \\
Asynchronous & $8(36)$ \\
Mix of synchronous and asynchronous & $1(5)$ \\
Preferred course delivery method during spring 2020 & \\
Synchronous & \\
Asynchronous & \\
Mix of synchronous and asynchronous & \\
Not applicable & \\
\hline & \\
\hline
\end{tabular}

\section{Data Analysis}

Responses were loaded into NVivo v10 Software (QSR International, Burlington, MA). Thematic analysis was completed using the steps published by Braun and Clarke (2006). Three investigators (two faculty members and one student) read all interview summaries several times. One faculty member coded all responses with review by the two other investigators. The investigators met to discuss and had high agreement. The group derived themes and subthemes from the data, reviewed and named them. Any discrepancies throughout the process were resolved by discussion. 


\section{RESULTS}

\section{Administration Response to Faculty Regarding Student Concerns}

The SoP Dean asked the Senior Associate Dean to share pharmacy students' concerns as expressed in the COVID-19 Student Survey to see if there were positive ways to address concerns that were academic in nature. A summary of pharmacy student survey responses during the time-period $(3 / 25 / 20-4 / 1 / 20)$ and some salient academic concerns expressed by pharmacy students during that time-period include:

1. Some faculty were "overcorrecting" for distance education by creating more work, more formalized work, or more difficult exams/quizzes.

2. Some faculty were extending their lectures going over their allotted class times.

3. Students with small children at home or other distractions were not able to take exams or quizzes at prescribed times, and in an equitable manner compared to other students without similar distractions.

(Document received 4-2-20: Senior Associate Dean; Subject: Student Academic Concerns).

\section{Response From the Department of Pharmacy Practice Chair}

The Chair of the Department of Pharmacy Practice reached out to the faculty to share student comments and request information about how faculty were adapting their coursework, especially in the abovementioned three areas of concern. Table 2 summarizes the changes in the program's pharmacy practice laboratory (i.e., Concept Laboratory) courses and Table 3 summarizes the changes to experiential education. The results of other faculty efforts are summarized below.

TABLE 2

\section{CHANGES MADE TO PHARMACY PRACTICE CONCEPT LAB ASSESSMENTS BY FACULTY DURING COVID-19 DISTANCE LEARNING}

\begin{tabular}{|c|c|c|}
\hline Class & Activity & Select summarized responses \\
\hline \multirow[t]{4}{*}{$\begin{array}{l}\text { First professional } \\
\text { year pharmacy } \\
\text { students }(\mathrm{P} 1 \mathrm{~s})\end{array}$} & $\begin{array}{l}\text { Dispensing \& } \\
\text { consultation practical } \\
\text { exam }\end{array}$ & $\begin{array}{l}\text { Used multiple forms of communication to relay } \\
\text { new exam process to students. Written portion } \\
\text { administered via ExamSoft with additional content } \\
\text { to replace in-person skills. } \\
\text { Exam available for } 24 \text {-hour window }\end{array}$ \\
\hline & $\begin{array}{l}\text { Non-sterile } \\
\text { compounding practical } \\
\text { exam }\end{array}$ & $\begin{array}{l}\text { Used multiple forms of communication to relay } \\
\text { new exam process to students. Written portion } \\
\text { administered via ExamSoft with additional content } \\
\text { to replace in-person skills. }\end{array}$ \\
\hline & & Online office hours held to answer questions \\
\hline & $\begin{array}{l}\text { Sterile compounding } \\
\text { practical exam }\end{array}$ & $\begin{array}{l}\text { Training via faculty created videos and CORE } \\
\text { readiness videos. Written portion administered via } \\
\text { ExamSoft. Skills portion changed to an oral exam } \\
\text { with faculty using Blackboard Collaborate }\end{array}$ \\
\hline
\end{tabular}




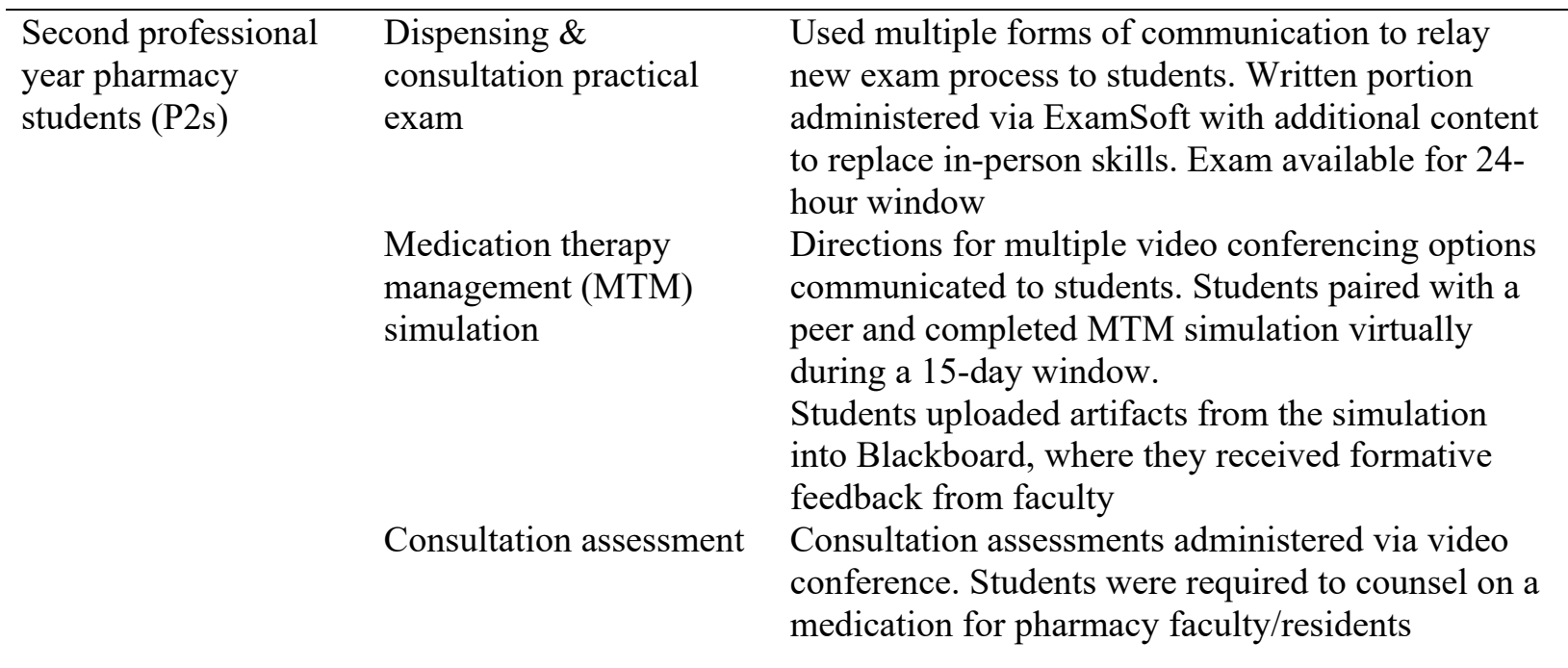

The results are drawn from a memo dated 4/6/2020 from the Chair of the Department of Pharmacy Practice to the Senior Associate Dean

TABLE 3

CHANGES MADE TO EXPERIENTIAL EDUCATION DURING COVID-19 DISTANCE LEARNING

\begin{tabular}{|c|c|c|}
\hline $\begin{array}{l}\text { Experiential } \\
\text { Education Type }\end{array}$ & $\begin{array}{l}\text { Experiential Education } \\
\text { Format pre COVID-19 }\end{array}$ & $\begin{array}{l}\text { School of Pharmacy Response During the } \\
\text { COVID-19 Pandemic }\end{array}$ \\
\hline $\begin{array}{l}\text { Advanced Pharmacy } \\
\text { Practice Experience } \\
\text { (APPE) }\end{array}$ & $\begin{array}{l}\text { Students required to } \\
\text { complete a 200-hour } \\
\text { rotation in community } \\
\text { pharmacy, } \\
\text { hospital/health system } \\
\text { pharmacy, ambulatory } \\
\text { patient care and } \\
\text { inpatient general } \\
\text { medicine patient care } \\
\text { and rural pharmacy as } \\
\text { well as three } 200 \text {-hour } \\
\text { elective rotations }\end{array}$ & $\begin{array}{l}\text { Reassigned students to sites still taking students if } \\
\text { possible. } \\
\text { When necessary repurposed completed rotation } \\
\text { hours in accordance with guidance from ACPE } \\
\text { Decreased from NDSU requirement of } 1600 \\
\text { experiential hours to ACPE requirement of } 1440 \\
\text { experiential hours. } \\
\text { Waived NDSU requirement of completing a rural } \\
\text { rotation. } \\
\text { Used CORE modules for elective hours if needed. } \\
\text { Completed a remote academic rotation with faculty } \\
\text { members if elective hours remained. } \\
\text { Hundreds of extra hours were spent by faculty and } \\
\text { staff to ensure all NDSU students who were } \\
\text { scheduled for a Spring } 2020 \text { graduation were able } \\
\text { to successfully graduate on time }\end{array}$ \\
\hline
\end{tabular}




\begin{tabular}{|c|c|c|}
\hline $\begin{array}{l}\text { Introductory } \\
\text { Pharmacy Practice } \\
\text { Experience (IPPE) }\end{array}$ & $\begin{array}{l}\text { Prior to the pandemic } \\
\text { after the P1 year } \\
\text { students would complete } \\
\text { a 3-week institutional } \\
\text { IPPE rotation and after } \\
\text { the P2 year a 4-week } \\
\text { community IPPE } \\
\text { rotation plus various } \\
\text { IPPE hours throughout } \\
\text { the regular curriculum }\end{array}$ & $\begin{array}{l}\text { Institutional sites were the most difficult to place. } \\
\text { During the pandemic P1 IPPE students were able } \\
\text { to complete an institutional IPPE rotation if } \\
\text { available. If unavailable, they were reassigned to a } \\
\text { community IPPE rotation and will plan to complete } \\
\text { an institutional IPPE rotation summer } 2021 \text {. } \\
\text { Community IPPE students were reassigned to a } \\
\text { different community IPPE site if they were not able } \\
\text { to complete their originally scheduled rotation. } \\
\text { Additionally, IPPE hours in the regular curriculum } \\
\text { were reduced however students normally complete } \\
\text { an excess of the } 300 \text { hours required by ACPE so } \\
\text { they did not fall below the threshold with the } \\
\text { pandemic. } \\
\text { A task force during the pandemic voted to } \\
\text { permanently change the order of IPPE going } \\
\text { forward. } \\
\text { Hundreds of extra hours were spent by faculty and } \\
\text { staff to ensure all NDSU students who desired to } \\
\text { complete rotations were able to stay on track for an } \\
\text { on-time graduation }\end{array}$ \\
\hline
\end{tabular}

$\mathrm{ACPE}=$ Accreditation Council for Pharmacy Education; NDSU=North Dakota State University

Results From the Department of Pharmacy Practice Faculty

The results reported to the Chair of the Department of Pharmacy Practice are summarized below.

\section{Exams}

Most faculty are allowing longer windows for exam completion than the typical class time (e.g., 9am to $1 \mathrm{pm}$ ), while still setting a time limit for the exam once it is started. No faculty member indicated an intention to shorten length of time for exam completion over what would normally be allotted in the faceto-face class. Faculty are communicating that exams are not, on average, being made more difficult than compared to similar courses in previous semester. In some cases, they are being adjusted to better accommodate the style of learning or assessment that is now taking place.

\section{Online Class Time and Communication}

In some cases, faculty have intentionally shortened their class delivery (especially when lectures have been pre-recorded) time into smaller segments of time than would normally occur in a face-to-face class setting. When complex material is covered, some faculty compensate by reducing virtual learning times needed to complete other parts of the course. Many faculty members also pre-record class content (or record live sessions) to make them available for students to view. Unfortunately, there have been some challenges as faculty adapt to remote (virtual) teaching technologies. While most faculty make a concerted effort to record content, lecture-recording has not always functioned perfectly.

Blackboard announcements, email, and weekly compressed video (i.e., Yuja) recordings have been used to communicate course contingencies and stay connected with students. Faculty are working to minimize the overall number of emails sent to students by consolidating information into a larger weekly/biweekly emails. (Summary of document received 4-6-2020. From: Chair, Pharmacy Practice; To: Senior Associate Dean; Subject: Student Academic Concerns).

\section{Administration Response to Pharmacy Student Concerns}

The Senior Associate Dean responded to the pharmacy student concerns with a memo to faculty and students. The Senior Associate Dean addressed faculty exceeding their allotted time, flexibility in setting 
exam times, inability to opt for pass/fail and ability for faculty to determine if they would disable backward navigation in Exam Soft.

\section{Faculty Survey Themes After the Completion of the Spring 2020 Semester}

Twenty-two of 38 faculty members participated in the survey (57.9\% response rate). Individual interviews ranged from 7-75 minutes in length (mean $=39$ minutes). Most participants were 30-39 years old $(n=9,40.9 \%)$ with no previous experience with distance or online education $(n=15,68.2 \%)$ who preferred synchronous course delivery prior to Spring $2020(\mathrm{n}=19,90.0 \%)$. Three main overarching themes were identified when reviewing the interview summaries: engagement/community, technology, and transition. Themes, subthemes and selected summarized responses are presented in Table 4.

TABLE 4

SUMMARY OF THEMES FROM FACULTY SURVEY

\begin{tabular}{|c|c|c|}
\hline Overarching themes & Sub-themes & Select summarized responses \\
\hline \multirow[t]{5}{*}{ Engagement/Community } & $\begin{array}{l}\text { Lack of non-verbal } \\
\text { feedback }\end{array}$ & $\begin{array}{l}\text { No nonverbal feedback from the students in } \\
\text { online format. Sometimes students ask questions } \\
\text { in chat but still not the same as visual. }\end{array}$ \\
\hline & $\begin{array}{l}\text { Decreased student } \\
\text { engagement }\end{array}$ & $\begin{array}{l}\text { Decreased for the most part. Didn't have cameras } \\
\text { on and it was hard to gauge their understanding } \\
\text { and how well they were following along. }\end{array}$ \\
\hline & Faculty felt supported & $\begin{array}{l}\text { Given the abrupt nature of the change felt like } \\
\text { the support was reasonable and adequate. }\end{array}$ \\
\hline & $\begin{array}{l}\text { Concerns about } \\
\text { student connections }\end{array}$ & $\begin{array}{l}\text { Most of them were missing their study groups } \\
\text { and connection with peers. }\end{array}$ \\
\hline & $\begin{array}{l}\text { Collusion } \\
\text { (Inappropriate } \\
\text { community) concerns }\end{array}$ & $\begin{array}{l}\text { Extra ExamSoft monitoring (looking at when } \\
\text { they started/ended), reminding students they are } \\
\text { professional students and signed code of } \\
\text { conduct. }\end{array}$ \\
\hline \multirow[t]{3}{*}{ Technology } & $\begin{array}{l}\text { Increased faculty } \\
\text { preparation time }\end{array}$ & $\begin{array}{l}\text { Spent more time preparing after the change } \\
\text { because felt like needed to cut down the } \\
\text { workload to make it more manageable for } \\
\text { extraordinary situation, threw old schedule out } \\
\text { and gave more time, and totally changed due } \\
\text { dates and deadlines to only two days of the } \\
\text { week. Replanned schedule and made proper } \\
\text { adjustments. In addition, a lot of the activities } \\
\text { and lecture material had to be a lot more spelled } \\
\text { out and coordinated so they could be done online } \\
\text { easier. Had extra time for office hours. }\end{array}$ \\
\hline & Used new technology & $\begin{array}{l}\text { Used Blackboard Collaborate, advising meetings } \\
\text { and student questions via Skype. }\end{array}$ \\
\hline & $\begin{array}{l}\text { Concerns about } \\
\text { access }\end{array}$ & $\begin{array}{l}\text { Technical issues were one big issue. Not } \\
\text { everyone has strong Wi-Fi to be able to do } \\
\text { everything. Also living with family and trying to } \\
\text { work from home was difficult. Hard to focus. }\end{array}$ \\
\hline
\end{tabular}


Transition

learning environment
Didactic wise- didn't change it a ton and continued with the same format. Tried to give more trust in students to be focused on the material and be discussing and learning the material. Experiential-made students a lot more responsible for their own learning. Children, roommates, family, etc. - a lot of outside distractions for the students. Made it harder for them to focus without dedicated learning environment.

\section{Engagement/Community}

"Engagement and community" emerged as a theme throughout the surveys. Included in this theme were numerous references to the lack of non-verbal feedback when teaching with distance or online education due to students generally not having their cameras on. This also contributed to overall decreased student engagement and concerns about student connections with peers and faculty. Overall, faculty reported feeling supported with the rapid need to change teaching style recognizing that everyone did the best they could. Within this theme, concerns about inappropriate community (i.e., collusion, cheating) were also present. Distance learning opened opportunities for collusion when students were no longer being physically proctored during assessments.

\section{Technology}

"Technology" emerged as the second theme. Many references to the use of new technology during the semester were reported including video conferencing (Blackboard collaborate, Zoom, Microsoft Teams, Skype), Yuja, CORE modules, ExamSoft, Eli Review, discussion boards, and online office hours. This understandably resulted in increased faculty preparation time not only to learn the new technology but also to revise the course delivery and critically evaluate importance of the content. Additionally, there were many concerns about access to technology, most notably strong Wi-Fi connection for students and faculty.

\section{Transition}

"Transition" was the final theme. Faculty had to transition quickly to distance learning. This required a change in teaching methods for many courses. Faculty reported some content was changed to asynchronous, attempts to simplify content/expectations and include better instructions, changes in assessment type, and some relied more heavily on students to be responsible for their own learning. Also, under the "transition" umbrella there were many comments about students needing to change their learning environment which presented new challenges. Several challenges identified included: student ability to focus and time management, increasing internship hours and living in different time zones. Other faculty commented on concerns about family distractions including children or family illness and mental health concerns including loss of peer support and study groups.

Many faculty members used this exposure to remote teaching as a learning experience and transition themselves. Faculty commented on changes they hoped to make for fall semester 2020. Several planned changes included: learning to use the Hy-Flex virtual learning methodology and new technology such as Zoom (more licenses and trainings were offered throughout the summer). Faculty also identified they would do better planning for fall and have multiple plans, simplify, change assessments, include more quizzes to keep students on track, encourage and engage students, use layered learning on experiential rotations and provide more consistent communication. 


\section{DISCUSSION}

The Coronavirus pandemic certainly has impacted people emotionally, physically, and financially, both globally and in the United States. The worst pandemic, the Bubonic Plague (Black Death) swept through Asia, Europe and Africa in the 14th century and killed an estimated 50 million people (25 to $50 \%$ of population) (Prentice \& Rahalison, 2007). The second worst pandemic is the 1918 Spanish Flu that affected 500 million people globally and killed about 50 million people. About $28 \%$ of the United States population of 105 million became infected and about 600,000 died (Centers for Disease Control and Prevention, 2018; Gagnon et al., 2013). The COVID-19 pandemic is possibly the second or third worst global pandemic in world history and the suffering of those affected and heart-breaking loss of loved ones caused by it, is unimaginable.

With every problem, an opportunity exists to address that problem. Health professionals such as physicians, nurses, respiratory therapists, and pharmacists have stepped up to meet this emergency crisis. The burden of long work hours combined with the emotional and physical toll health care professionals meet daily, clearly demonstrates how a crisis can bring out the best of humanity. The faculty and students at NDSU have also stepped up to meet this crisis. Our faculty have varying experience using remote learning techniques, from limited to none. While most faculty are comfortable in the classroom, they are less comfortable with remote learning. In a very short period (about one week), faculty have stepped up and delivered in this crisis.

Students have also adapted to remote learning and several issues have arisen. Many of these issues were identified by the ongoing survey of students that was administered by the School of Pharmacy administrative team. The major issues were identified and summarized (e.g., online class time, communication with students, flexibility in administering exams) and shared with the faculty members and students, so we can learn from each other in these difficult times.

Many of the foundational courses in the Doctor of Pharmacy curriculum are similar from one ACPEaccredited program to the next. Remote (virtual) learning may be a logical progression of the flipped classroom and hybrid classroom initiatives that already exist in many schools, and there is a need for faculty to serve as coaches, moderate online discussions, and provide feedback. Coyne et al. (2019) reported on using virtual reality technology as an interactive learning environment, and with further development, virtual reality has the potential to become an integral part of pharmacy education. Lichvar et al. (2016) integrated virtual activity into a required therapeutics course using a dynamic virtual-patient case (complications of liver disease) that students worked through during the class and concluded that it is an effective active-learning strategy. Other authors also report on the benefits of virtual learning in pharmacy education (Ferreri \& O'Connor, 2013; McLaughlin et al., 2013; Pierce \& Fix, 2012). As demonstrated by the NDSU faculty survey and the student survey findings, the level of virtual learning is inconsistent across the faculty, yet mostly due to the impact of the COVID-19 pandemic, this transition was expedited. For example, our concept laboratory has long been a leader in active learning and technology innovators in student learning. During this crisis, the pharmacy practice laboratory (i.e., Concept Laboratory) and experiential education faculty were proactive and made numerous changes to address the needs of students (Table 2 and 4). Other faculty in the SoP also stepped-up and delivered during this crisis. Faculty now use a variety of platforms to coach students, facilitate virtual discussions and assessments. They continue to refine their teaching as the pandemic continues. Overall, faculty, staff, students, and administration in the NDSU SoP met this challenge and achieved mostly positive outcomes during this difficult period. Together, we look forward to better times and meeting the challenges in the future.

During the COVID-19 pandemic, pharmacy schools have faced the removal of students from some of their clinical rotations. Pharmacy schools like Purdue University, Rutgers University and Washington State University graduated their students' early (Huchel, 2020; Makin, 2020; Washington State University College of Pharmacy and Pharmaceutical Sciences, 2020). In 2020 many teaching sites canceled APPE and/or IPPE rotations. Similarly, NDSU experiential faculty met many issues in APPE rotations such as reducing hours, repurposing hours, and moving students to alternate rotation sites, so that all students could and did graduate on time. The ACPE limits simulation hours and defines appropriate use within IPPE and 
requires the majority of APPE to include direct patient care (Accreditation Council for Pharmacy Education, 2015). Problem-specific patient interviewing, disease presentations, and team training are a few of the potential applications of virtual reality educational programs (Hollander \& Carr, 2020). While virtual clinical learning is a technique that offers promise, there is no substitute for actual world experience in community, institutional and other pharmacy practice settings.

\section{Volunteer Public Health Opportunities During the COVID-19 Crisis}

Many crises including, the COVID-19 pandemic is viewed as extremely negative, with major outcomes including illness, mortality, unemployment, and financial challenges, among a host of other detriments. This manuscript also highlights several positive outcomes, including the willingness of SoP faculty to ensure that students continue to receive a quality education. Perhaps more impressive are the extraordinary efforts of health professionals to offer - over and above the routine professional responsibilities - their personal time and safety to care for COVID-19 patients. The pandemic offered an opportunity for health professions students in the NDSU College of Health Professions (including Doctor of Pharmacy students) to contribute to these efforts through contact tracing.

\section{Interpretation of Survey Results}

Many of the student concerns and faculty impressions of the semester are overlapping and intertwined. Students cited concerns with the transition to remote learning including faculty "overcorrecting" and creating more work and more difficult assessments. These concerns can be tied to the faculty's comments about needing to transition course delivery quickly, which likely resulted in difficulty estimating completion time of activities and assignments in a new format. Additionally, some faculty reported they simplified material which was likely in part in response to the information relayed from the student surveys. Assessment formats had to transition quickly to remote which led to faculty concerns about collusion and cheating resulting in changes to assessments to circumvent these concerns.

Students reported that faculty were extending lectures. With the variety of technology, faculty had to learn quickly, and so this concern is not surprising. For example, extra time was needed to open the technology and start the class, troubleshoot technology issues, move students to breakout rooms and manage chat questions. This new process understandably may have resulted in it taking longer to cover material previously appropriate for the allotted class time. Finally, students cited concerns about distractions during exam windows. The faculty survey revealed faculty were aware of these issues' students were facing. Many faculty opted to increase the exam windows as suggested by administrators to accommodate students.

\section{Implications}

COVID-19, while devastating, also includes some silver linings. Students have exposure to public health topics daily in the news, at school, work, and on rotations. Faculty have transitioned teaching methods and activities to remote learning that some would never have attempted or believed could be done. This transition is challenging faculty to reconceptualize the classroom and what is truly necessary for learning. Open communication among all stakeholders continues to be important as we go forward and approach this pandemic as a team.

\section{Limitations}

There are several limitations to the student study and report. The first limitation is that this is a natural (observational) study performed at a single site (at one Midwestern university). The results are not necessarily generalizable to other colleges and universities in other states. A second limitation is scope and nature of the survey itself. The response rate to the student survey was not measured in a scientific way. Those that responded may or may not be representative of the entire student population. The results may be biased or skewed in the direction of overly positive or negative responses.

There were also several limitations to the faculty interview survey. The first is the incomplete nature of some of the items. In one interview, the interviewer did not follow-up with the interviewee when the time limit expired, and one question remained unanswered. This could lead to an inaccurate response from 
this participant. Interviews were not recorded and were transcribed as summaries without interviewee review which could have led to errors of omission or incorrect interpretation of responses. Two administrators were included in the faculty survey who did not have teaching responsibilities in the spring but were intimately involved in the transition to remote learning. Finally, interviews were not offered to other faculty members who did not formally teach in the PharmD coursework in the spring. These faculty would still have advisees and possibly graduate students which may have resulted in different responses.

\section{CONCLUSIONS}

The emergency response to the COVID-19 pandemic by schools of pharmacy in meeting the needs of our students has been extraordinary. It has been a real eye opener for us to see what our students are dealing with and the information we are gathering is quite empowering giving us an opportunity to address specific needs as they arise. Measuring the impact of remote learning is crucial, now and in the future.

\section{ACKNOWLEDGMENTS}

The authors acknowledge the pharmacy students and faculty who participated in the survey and the faculty who made the necessary changes in pharmacy education that were created by the COVID-19 pandemic crisis.

\section{REFERENCES}

Accreditation Council for Pharmacy Education. (2015, February 2). Accreditation standards and key elements for the professional program in pharmacy leading to the Doctor of Pharmacy degree ("Standards 2016"). Retrieved June 8, 2021, from https://www.acpeaccredit.org/pdf/Standards2016FINAL.pdf

Anderson, C., Bates, I., Beck, D., Brock, T., Futter, B., Mercer, H., . . Yonemura, A. (2009). The WHO UNESCO FIP pharmacy education taskforce. Human Resources for Health, 7, Article 45.

Retrieved June 8, 2021, from https://human-resourceshealth.biomedcentral.com/articles/10.1186/1478-4491-7-45

Braun, V., \& Clarke, V. (2006). Using thematic analysis in psychology. Qualitative Research in Psychology, 3(2), 77-101.

Brazeau, G., \& Romanelli, F. (2020). Navigating the uncharted waters in the time of COVID-19. American Journal of Pharmaceutical Education, 84(3), Article 8063. Retrieved June 8, 2021, from https://www.ncbi.nlm.nih.gov/pmc/articles/PMC7159014/pdf/ajpe8063.pdf

Brown, W., Scott, D., Friesner, D., \& Schmitz, T. (2017). Impact of telepharmacy services as a way to increase access to asthma care. Journal of Asthma, 54(9), 961-967.

Centers for Disease Control and Prevention. (2018, March 21). Pandemic History. Retrieved June 8, 2021, from https://www.cdc.gov/flu/pandemic-resources/1918-commemoration/1918-pandemichistory.htm

Coyne, L., Merritt, T., Parmentier, B., Sharpton, R., \& Takemoto, J. (2019). The past, present, and future of virtual reality in pharmacy education. American Journal of Pharmaceutical Education, 83(3), Article 7456. Retrieved June 8, 2021, from https://www.ajpe.org/content/83/3/7456

Education Week. (2020, September 16). Map: Coronavirus and School Closures. Retrieved June 8, 2021, from https://www.edweek.org/leadership/map-coronavirus-and-school-closures-in-20192020/2020/03

Ferreri, S., \& O'Connor, S. (2013). Redesign of a large lecture course into a small group learning course. American Journal of Pharmaceutical Education, 77(1), Article 13. Retrieved June 8, 2021, from https://www.ajpe.org/content/77/1/13

Forister, J., \& Blessing, J. (2020). Introduction to Research and Medical Literature for Health Professionals (5th Edition). Jones \& Bartlett Learning. 
Friesner, D., Miller, D., Scott, D., Naughton, C., \& Albano, C. (2010). Rural public health education as a pharmacist-led team endeavor. Journal of the American Pharmacists Association, 50(2), 207213.

Fuller, K., Heldenbrand, S., Smith, M., \& Malcom, D. (2020). A paradigm shift in us experiential pharmacy education accelerated by the COVID-19 pandemic. American Journal of Pharmaceutical Education, 84(6), Article 8149. Retrieved June 8, 2021, from https://www.ajpe.org/content/84/6/ajpe8149

Gagnon, A., Miller, M., Hallman, S., Bourbeau, R., Herring, D., Earn D.J., \& Madrenas, J. (2013). Agespecific mortality during the 1918 influenza pandemic: Unravelling the mystery of high young adult mortality. PLOS One, 8(8), Article e69586. Retrieved June 8, 2021, from https://journals.plos.org/plosone/article?id=10.1371/journal.pone.0069586

Hadden, J., Casado, L., \& Bose, D. (2020, March 24). Columbia, Harvard, NYU, and other major US colleges and universities that have switched to remote classes and are telling students to move out of dorms to prevent the spread of the coronavirus. Business Insider. Retrieved June 8, 2021, from $\mathrm{https}$ ://www.businessinsider.com/major-colleges-and-universities-going-remote-overcoronavirus-fears

Hollander, J., \& Carr, B. (2020). Virtually perfect? Telemedicine for Covid-19. New England Journal of Medicine, 382, 1679-1681.

Huchel, B. (2020, April 9). Pharmacy students to graduate early in preparation for future COVID-19 impact. Retrieved June 8, 2021, from https://www.purdue.edu/newsroom/releases/2020/Q2/pharmacy-students-to-graduate-early-inpreparation-for-future-covid-19-impact.html

Hui, D., Azhar, E., Madani, T., Ntoumi, F., Kock, R., Dar, O., . . Petersen, E. (2020). The continuing 2019-nCoV epidemic threat of novel coronaviruses to global health - The latest 2019 novel coronavirus outbreak in Wuhan, China. International Journal of Infectious Diseases, 91, 264 266.

Kebritchi, M., Lipschuetz, A., \& Santiague, L. (2017). Issues and challenges for teaching successful online courses in higher education: A literature review. Journal of Educational Technology Systems, 46(1), 4-29.

Kim, C., Lynch, J., Cohen, S., Neme, S., Staiger, T., Evans, L., . . Dellit, T.H. (2020). One academic health system's early (and ongoing) experience responding to COVID-19: Recommendations from the initial epicenter of the pandemic in the United States. Academic Medicine, 95(8), 11461148.

Lichvar, A., Hedges, A., Benedict, N., \& Donihi, A. (2016). Combination of a flipped classroom format and a virtual patient case to enhance active learning in a required therapeutics course. American Journal of Pharmaceutical Education, 80(10), Article 175. Retrieved June 8, 2021, from https://www.ajpe.org/content/80/10/175.abstract

Lurie, N., \& Carr, B.G. (2018). The role of telehealth in the medical response to disasters. JAMA Internal Medicine, 178(6), 745-746.

Lyons, K., Christopoulos, A., \& Brock, Y. (2020). Sustainable pharmacy education in the time of COVID-19. American Journal of Pharmaceutical Education, 84(6), Article 8088. Retrieved June 8, 2021, from https://www.ajpe.org/content/84/6/ajpe8088

Makin, B. (2020, April 3). Coronavirus: Rutgers to graduate pharmacy students early to help on front lines. My Central Jersey. Retrieved June 8, 2021, from https://www.mycentraljersey.com/story/news/education/college/rutgers/2020/04/02/coronavirusnj-rutgers-school-pharmacy-move-up-graduation/5117180002/

McLaughlin, J., Griffin, L., Esserman, D., Davidson, C., Glatt, D., Roth, M., . . Mumper, R. (2013). Pharmacy student engagement, performance, and perception in a flipped satellite classroom. American Journal of Pharmaceutical Education, 77(9), Article 196. Retrieved June 8, 2021, from https://www.ajpe.org/content/77/9/196 
Moule, P., Ward, R., \& Lockyer, L. (2010). Nursing and healthcare students' experiences and use of elearning in higher education. Journal of Advanced Nursing, 66(12), 2785-2795.

Murphy, J. (2020, April 4). Pharmacy students, professors continue to adjust to COVID-19. Pharmacy Times. Retrieved June 8, 2021, from https://www.pharmacytimes.com/view/pharmacy-studentsprofessors-continue-to-adjust-to-covid-19

Naughton, C., Friesner, D., Scott, D., Miller, D., \& Albano, C. (2010). Designing a Master of Public Health degree within a department of pharmacy practice. American Journal of Pharmaceutical Education, 74(10), Article 186. Retrieved June 8, 2021, from https://www.ajpe.org/content/74/10/186

Peterson, C., Scott, D., Rathke, A., Killingsworth, P., \& Hill, G. (2010). Establishing a central order entry site for delivering telepharmacy services to remote rural hospitals. Journal of Pharmacy Technology, 26, 179-186.

Pierce, R, \& Fix, J. (2012). Vodcasts and active-learning exercises in a "flipped classroom" model of a renal pharmacotherapy module. American Journal of Pharmaceutical Education, 76(10), Article 196. Retrieved June 8, 2021, from https://www.ajpe.org/content/76/10/196

Prentice, M., \& Rahalison, L. (2007). Plague. The Lancet, 369(9568), 1196-1207.

Schlesselman, L., Cain, J., \& DiVall, M. (2020). Improving and restoring the well-being and resilience of pharmacy students during a pandemic. American Journal of Pharmaceutical Education, 84(6), Article 8144. Retrieved June 8, 2021, from https://doi.org/10.5688/ajpe8144

Scott, D., Friesner, D., Undem, T., Anderson, G., Sem, K., \& Peterson, C. (2017). Sustainability of community telepharmacy in North Dakota. Journal of the American Pharmacists Association, 57(3), P362-P368.E5.

Volery, T., \& Lord, D. (2000). Critical success factors in online education. International Journal of Education Management, 14(5), 216-223.

Washington State University College of Pharmacy and Pharmaceutical Sciences. (2020, April 27). CPPS COVID-19 updates and communications. Retrieved June 8, 2021, from https://pharmacy.wsu.edu/cpps-covid-19-updates-and-communications/

Woolliscroft, J. (2020). Innovation in response to the COVID-19 pandemic crisis. Academic Medicine, 95(8), 1140-1142.

World Health Organization. (2020, January 26). Advice for public. Retrieved June 8, 2021, from https://web.archive.org/web/20200126025750/https:/www.who.int/emergencies/diseases/novelcoronavirus-2019/advice-for-public 


\section{APPENDIX: FACULTY INTERVIEW QUESTIONS}

1. What was your biggest challenge with transitioning to and teaching online courses?

2. What was the biggest external or environmental barrier you faced with transitioning to and teaching online courses?

3. How did your time spent preparing for class change once you transitioned from face-to-face to online teaching?

4. What adjustments, if any, did you make to your teaching style once your course transitioned to online?

5. Did you utilize any additional online resources, references, or technology you normally wouldn't have used to help facilitate learning once your course transition to online?

6. Was collusion between students a concern of yours? If so, what did you do to monitor this or track it?

7. What did you perceive to be the biggest challenge for students with the transition to online courses?

8. What did you perceive to be the biggest external or environmental barrier for students with the transition to online courses?

9. How would you describe student engagement with the instructor, other students, and the course content after the transition to online courses? (increased, decreased, or didn't change)

10. What type of effect do you believe the transition to online courses and the COVID-19 pandemic will have on the student's futures?

11. Do you feel like you were properly supported by NDSU in the transition to online courses? If not, what do you think is the best way NDSU could have supported you with the transition?

12. What is something (if anything) you plan to address or do differently if you were to have to do something like this again?

13. Do you feel like you had all the necessary resources and training to be successful in teaching an online course? Why or why not? 